\title{
Integrated Control of Phytophthora Root Rot of Red Raspberry
}

\author{
W. F. Wilcox, Department of Plant Pathology, Cornell University, New York State Agricultural Experiment Station, \\ Geneva 14456; and M. P. Pritts and M. J. Kelly, Department of Fruit and Vegetable Science, Cornell University, \\ Ithaca, NY 14853
}

\begin{abstract}
Wilcox, W. F., Pritts, M. P., and Kelly, M. J. 1999. Integrated control of Phytophthora root rot of red raspberry. Plant Dis. 83:1149-1154.

Various components of an integrated program for controlling Phytophthora root rot of red raspberries were examined in a factorial experiment conducted for three growing seasons in a silty clay loam naturally infested with Phytophthora fragariae var. rubi. The factors were: (i) cultivar (highly susceptible Titan versus moderately resistant Newburgh); (ii) bed height (flat versus raised); (iii) straw mulch application (yes versus no); (iv) preplant treatment with the biological control fungus Trichoderma (=Gliocladium) virens (yes versus no); and (v) seasonal applications of the fungicide metalaxyl (yes versus no). Disease incidence was assessed visually, and severity was measured with respect to cane density, cane vigor, and yield. Cultivar was the most important factor, having a highly significant $(P<0.0001)$ main effect on nearly every measure of disease incidence and severity; it also interacted significantly with most other factors for at least some of these measures. In general, such interactions resulted from the positive response of Newburgh to treatments that had little effect on the consistently poor growth and yield of Titan, or from the variable response of Titan to treatments that had little effect on the consistently low visual disease ratings for Newburgh. Raised bed cultivation consistently reduced disease incidence and improved plant performance (particularly for Newburgh) and was the only factor other than cultivar that significantly improved yield, i.e., 5.6 versus $2.0 \mathrm{~kg}$ per Newburgh plot on raised versus flat beds, respectively. Although metalaxyl initially provided a substantial decrease in disease incidence on Titan, most of these plants eventually died. In contrast, metalaxyl provided modest yield benefits for Newburgh, and highest yields were obtained when metalaxyl was used in conjunction with raised beds, i.e., means of 2.2 versus $1.8 \mathrm{~kg}$ for the treated versus untreated plots on flat beds and 6.3 versus $5.1 \mathrm{~kg}$, respectively, on raised beds. Straw mulch increased soil moisture levels and exacerbated disease incidence and severity. The biocontrol treatment had relatively little effect on disease, although there was some indication of marginally improved plant growth in treated plots.
\end{abstract}

Although Phytophthora root rot (PRR) was first described on red raspberries (Rubus idaeus) in 1934 (19), for a long time thereafter the disease was poorly understood and considered to be of only regional importance (1). However, multiple reports of newly recognized disease outbreaks on raspberries in Europe $(4,6,11$, 13,15), North America (20), South America (7), and Australia (18) brought PRR to international attention during the 1980s, and it now is recognized as one of the most serious maladies of red raspberries worldwide (21). At least 10 Phytophthora spp. have been implicated as causal agents of the disease, but $P$. fragariae var. rubi appears to be the most common and important in the cool, wet production regions of North America, northern Europe, and southern Chile $(2,4,6,13,20,23)$. This same fungus also has been referred to as $P$.

Corresponding author: W. F. Wilcox

E-mail: wfw1@cornell.edu

Accepted for publication 4 September 1999.

Publication no. D-1999-1019-01R

(C) 1999 The American Phytopathological Society selection, metalaxyl application, and mulching with respect to disease development under Norway's growing conditions.

PRR is a serious and common disease of red raspberries in New York, particularly on finer-textured soils with limited internal drainage. Thus, the question has been raised: can the disease be ameliorated sufficiently by improving the internal drainage of the soil (e.g., by installing drain tiles) rather than by the more complicated and less conventional system of constructing and maintaining raised beds? Furthermore, the relative effects of and interactions among various control components that might affect PRR, other than ridging and metalaxyl applications, have not been studied in North America. Therefore, this study was designed to examine the effects of various cultural practices and chemical and biological control treatments on the development of PRR on red raspberries. Our objective was to determine the most effective components of an integrated control program.

\section{MATERIALS AND METHODS}

Plot establishment and maintenance. The study was conducted at the Cornell Orchards in Ithaca, New York, in a field that previously had supported a raspberry planting severely diseased by $P$. fragariae var. rubi. The soil was a silty clay loam of the Hudson series (Typic Hapludalf), characterized by poor internal drainage and high water-holding capacity. In late summer of 1990, the surviving individuals from this previous planting were removed, the site was plowed and disked in preparation for the following year, and drain tiles were installed at a depth of 75 to $90 \mathrm{~cm}$.

In May 1991, 12 rows spaced $4 \mathrm{~m}$ apart were established roughly parallel to and straddling six drain lines. Raised beds were formed in alternate rows prior to planting; beds were $30 \mathrm{~cm}$ high $\times 1 \mathrm{~m}$ wide at the start of the experiment but had settled and eroded to a height of approximately $20 \mathrm{~cm}$ by its conclusion 2.5 years later. In late May, six tissue-cultured raspberry "plug" plants, propagated in a soilless potting mix by a commercial nursery (Nourse Farms, Whatley, MA), were transplanted at 0.8-m intervals within the row of each individual 4.8-m-long plot. Twenty orthogonal treatments resulting from various combinations of five contrasting factors were imposed (Table 1). These factors were: (i) cultivar (highly susceptible Titan versus moderately resistant Newburgh), (ii) bed height 
(flat versus raised), (iii) straw mulch application (yes versus no), (iv) preplant treatment with the biological control fungus Trichoderma (=Gliocladium) virens (yes versus no), and (v) seasonal applications of the fungicide metalaxyl (yes versus no).

T. virens treatments were established using an isolate (\#041) originally recovered from a soil suppressive to Aphanomyces root rot of pea, which has provided biocontrol of Phytophthora cactorum on apple seedlings (16) and $P$. sojae on soybean seedlings (22) under greenhouse conditions. Conidia and chlamydospores of the fungus were produced on autoclaved wheat bran as described by Smith et al. (16), and 1 liter of this inoculum was incorporated by hand into each designated planting hole (approximately $30 \mathrm{~cm}$ diameter $\times 30 \mathrm{~cm}$ deep) immediately before transplanting. A soil sample was removed from each treated site and four untreated sites immediately after the inoculum was incorporated; then three replicate 10 -g subsamples from each site were serially diluted and assayed for their $T$. virens population densities by plating on TSM selective medium (16). Mean densities ranged from $1.0 \times 10^{4}$ to $5.0 \times 10^{5} \mathrm{CFU} / \mathrm{g}$ of soil for the treated sites, whereas 11 of the 12 subsamples from untreated sites yielded no $T$. virens and one yielded $2.0 \times 10^{3} \mathrm{CFU} / \mathrm{g}$.

Straw mulch was applied to designated plots to a depth of $15 \mathrm{~cm}$ in a 1-m-wide band over the row immediately after planting, and again in the spring of 1992. Metalaxyl was applied to designated plots in autumn of the establishment year at the labeled rate of $0.4 \mathrm{~g}(1.55 \mathrm{ml}$ of Ridomil 2E) per meter of row in a 1-m-wide band over the row, and was reapplied in the early spring and fall of each subsequent year. Tensiometers (Irrometer Co., Riverside, CA) were installed near the center of designated plots in early summer of 1991 at a soil depth of $25 \mathrm{~cm}$ and were maintained throughout subsequent growing seasons. Each of the three replicate plots of four factorial combinations for Titan (treatments 1 through 4) and one replicate plot of the same combinations for Newburgh (treatments 11 through 14) were selected to compare the effects of mulching and bed height on soil moisture status. Tensiometers were read irregularly during the summer (i.e., on 13, 16, and 2 separate days in 1991 to 1993 , respectively), concentrating on periods following significant rainfall in order to detect potential differences in drainage and/or drying rates. For each bed height $\times$ mulch combination,

Table 1. Specific orthogonal treatments resulting from the combinations of various cultural, chemical, and biological factors examined for their utility in an integrated program for control of Phytophthora root rot

\begin{tabular}{ccccc}
\hline \multirow{2}{*}{$\begin{array}{c}\text { Treatment number } \\
\text { (Titan, Newburgh) }\end{array}$} & \multicolumn{4}{c}{ Factor } \\
\cline { 2 - 5 } & Bed height & Mulch & Trichoderma & Metalaxyl \\
\hline 1,11 & Flat & - & - & - \\
2,12 & Flat & + & - & - \\
3,13 & Raised & - & - & - \\
4,14 & Raised & + & - & - \\
5,15 & Flat & - & - & + \\
6,16 & Flat & - & + & - \\
7,17 & Flat & - & + & + \\
8,18 & Raised & - & - & + \\
9,19 & Raised & - & + & + \\
10,20 & Raised & - & + & + \\
\hline
\end{tabular}

readings from the Titan and Newburgh plots were combined to provide four replicate water tension measurements.

Standard cultural practices were followed throughout the study (14); pest control was based on need and followed local commercial recommendations. Water was provided by trickle irrigation immediately after planting and subsequently when tensiometer readings exceeded $80 \mathrm{kPa}$ in the majority of the raised bed-unmulched plots: once in August 1991, once in August 1992, and approximately every 10 days in July and August 1993.

Data collection and analysis. The incidence of canes with typical symptoms of PRR (21) was determined for each plot in July and August 1992. In October 1992, the length of 10 representative primocanes (first-year canes) was measured, as was the diameter of 20 representative primocanes at a point approximately $15 \mathrm{~cm}$ above the soil line. The total number of primocanes per plot was recorded in October 1992 and September 1993. All plants in each plot were harvested every 2 to 3 days from 13 July through 2 August 1993, and the cumulative weight from all pickings was used to determine yield.

The experimental design was a split plot, with bed height factor as the wholeplot treatment and cultivar, mulch, $T$. virens, and metalaxyl as the subplot treatments. Subplot treatments were assigned at random within whole plots. Each treatment was replicated three times. Analysis of variance (SuperANOVA 1.11) was used to determine the significance of main effects and interactions. Correlation analysis (StatView 4.5) was used to examine the intensity of association between dependent variables. For correlations involving soil water tension, data were used only from Titan plots in treatments 1 through 4 .

\section{RESULTS}

The 1991 growing season was relatively dry, with $39,27,101,66$, and $81 \mathrm{~mm}$ of

Table 2. Mean values for measurements of disease incidence, cane growth, and yield with respect to the main effects of various cultural, chemical, and biological control factors

\begin{tabular}{|c|c|c|c|c|c|c|c|c|}
\hline \multirow[b]{2}{*}{ Factor } & \multirow[b]{2}{*}{ Level } & \multicolumn{2}{|c|}{$\%$ diseased canes, $1992^{a}$} & \multicolumn{3}{|c|}{ Cane growth, Oct. 1992 ${ }^{\mathrm{b}}$} & \multicolumn{2}{|c|}{1993} \\
\hline & & 2 July & 25 August & Number & Length $(\mathbf{c m})$ & Diam. (mm) & No. canes $^{\mathrm{c}}$ & Yield $(\mathrm{kg})^{\mathrm{d}}$ \\
\hline \multirow[t]{2}{*}{ Cultivar } & Newburgh & 1.2 & 4.8 & 90.2 & 104.2 & 7.4 & 121.3 & 3.79 \\
\hline & Titan & 28.6 & 46.1 & 18.2 & 78.8 & 8.1 & 12.4 & 0.28 \\
\hline \multirow[t]{2}{*}{ Bed height } & Raised & 4.7 & 17.2 & 70.3 & 106.1 & 8.8 & 84.8 & 3.03 \\
\hline & Flat & 25.1 & 33.7 & 38.1 & 76.9 & 6.8 & 48.9 & 1.04 \\
\hline \multirow[t]{2}{*}{ Straw mulch } & Yes & 30.7 & 51.0 & 61.6 & 76.1 & 6.9 & 57.7 & 1.81 \\
\hline & No & 11.0 & 19.1 & 52.3 & 95.3 & 8.0 & 69.1 & 2.09 \\
\hline \multirow[t]{2}{*}{ Metalaxyl } & Yes & 6.3 & 14.2 & 54.9 & 99.8 & 8.2 & 72.4 & 2.33 \\
\hline & No & 20.6 & 33.0 & 53.7 & 85.9 & 7.5 & 63.1 & 1.83 \\
\hline \multirow{2}{*}{ Trichoderma } & Yes & 9.0 & 15.6 & 52.9 & 96.9 & 8.0 & 77.8 & 2.07 \\
\hline & No & 18.8 & 32.0 & 55.0 & 87.9 & 7.6 & 59.5 & 2.00 \\
\hline
\end{tabular}

a Total number of diseased and healthy canes within the boundaries of each plot were determined on indicated dates, based upon typical aerial symptoms of Phytophthora root rot.

${ }^{\mathrm{b}}$ For each plot, total number of primocanes within the boundary of each $4.8-\mathrm{m}$ plot was determined, as were mean height and diameter of 10 and 20 representative primocanes per plot, respectively.

c For each plot, total number of primocanes within the plot boundary was determined in September 1993.

$\mathrm{d}$ Yields were determined by harvesting all fruit from each plot throughout the respective commercial picking seasons for both cultivars. 
rain recorded in Ithaca during the months of May through September, respectively. No symptoms of PRR were observed during this initial season. In contrast, the summer of 1992 was unusually wet: 81 , $73,191,101$, and $129 \mathrm{~mm}$ of rain were recorded in the months of May through September, respectively. Symptoms of PRR were noticed first in June, after which the incidence of symptomatic canes increased progressively throughout the summer, as indicated by the differences between the 2 July and 25 August ratings (Table 2). The 1993 season also was relatively dry, with $39,117,60,63$, and 114 $\mathrm{mm}$ of rain recorded in the months of May through September, respectively.

Cultivar was the most important factor with respect to disease incidence, plant growth, and yield, providing highly significant $(P<0.0001)$ main effect differences for nearly every measure of disease incidence and severity (Table 3). For instance, when averaged across all treatments, nearly half of the Titan canes showed disease symptoms by late August 1992 versus <5\% for Newburgh; similarly, Newburgh produced fivefold as many primocanes as Titan by October, with mean lengths nearly one-third greater (Table 2). By 1993, nearly all Titan fruiting canes (i.e., the previous season's primocanes) were dead or dying (data not shown), resulting in extremely low yields, and very few new primocanes were present to serve as the source of the following year's crop. In contrast, mean yield and primocane density were 14- and 10-fold higher, respectively, in the Newburgh versus Titan treatments (Table 2).

Cultivar also was a factor in four of the five two-way interactions with $P<0.05$, and in 10 of the 11 with $P<0.10$ (Table 3). In general, these interactions resulted from either the positive response of Newburgh to treatments that had little effect on the consistently poor growth and yield of Titan, or from the variable response of Titan to treatments that had little effect on the consistently low disease incidences for Newburgh. For instance, both primocane number and yield were low across all Titan treatments in 1993, whereas the number of Newburgh primocanes increased from 93 to 149 and yield increased from 2.0 to 5.6 $\mathrm{kg}$ per plot in comparisons of flat versus raised beds, respectively (Table 4). Similarly, the mean number of Newburgh primocanes in 1993 increased to 141 from 108 in the presence and absence of the $T$. virens amendment, respectively, versus means of only 14 and 11 primocanes for Titan in the same respective treatments.

Conversely, metalaxyl ameliorated disease incidence and straw mulch exacerbated it for Titan, whereas disease inci-

Table 3. Significance values for main and interactive effects obtained from analyses of variance for measurements of disease incidence, cane growth, and yield variables

\begin{tabular}{|c|c|c|c|c|c|c|c|c|}
\hline \multirow[b]{2}{*}{ Source of variation } & \multirow[b]{2}{*}{ df } & \multicolumn{3}{|c|}{ Cane growth, Oct. 1992} & \multicolumn{2}{|c|}{$\%$ diseased canes } & \multicolumn{2}{|c|}{1993} \\
\hline & & Number & Length & Diam. & 2 Jul. 92 & 25 Aug. 92 & No. canes & Yield \\
\hline Bed height & 1 & 0.36 & 0.16 & 0.09 & 0.08 & 0.25 & 0.07 & 0.42 \\
\hline Error $^{\mathrm{a}}$ & 4 & & & & & & & \\
\hline Cultivar & 1 & 0.0001 & 0.0001 & 0.08 & 0.0001 & 0.0001 & 0.0001 & 0.0001 \\
\hline Straw mulch & 1 & 0.16 & 0.15 & 0.01 & 0.02 & 0.002 & 0.85 & 0.87 \\
\hline Trichoderma & 1 & 0.86 & 0.51 & 0.87 & 0.36 & 0.14 & 0.05 & 0.97 \\
\hline Metalaxyl & 1 & 0.46 & 0.06 & 0.24 & 0.03 & 0.04 & 0.46 & 0.28 \\
\hline Cultivar $\times$ bed & 1 & 0.53 & 0.52 & 0.61 & 0.01 & 0.16 & 0.09 & 0.02 \\
\hline Cultivar $\times$ mulch & 1 & 0.07 & 0.35 & 0.68 & 0.08 & 0.03 & 0.76 & 0.96 \\
\hline Cultivar $\times$ Trichoderma & 1 & 0.49 & 0.94 & 0.90 & 0.45 & 0.55 & 0.07 & 0.69 \\
\hline Cultivar $\times$ metalaxyl & 1 & 0.80 & 0.13 & 0.97 & 0.04 & 0.08 & 0.89 & 0.41 \\
\hline Bed $\times$ mulch & 1 & 0.55 & 0.14 & 0.03 & 0.56 & 0.46 & 0.70 & 0.49 \\
\hline Bed $\times$ Trichoderma & 1 & 0.93 & 0.98 & 0.16 & 0.67 & 0.88 & 0.82 & 0.71 \\
\hline Bed $\times$ metalaxyl & 1 & 0.79 & 0.53 & 0.18 & 0.08 & 0.65 & 0.99 & 0.79 \\
\hline Trichoderma $\times$ metalaxyl & 1 & 0.67 & 0.13 & 0.79 & 0.93 & 0.30 & 0.67 & 0.79 \\
\hline Bed $\times$ cult $\times$ mulch & 1 & 0.60 & 0.58 & 0.64 & 0.28 & 0.14 & 0.98 & 0.62 \\
\hline Bed $\times$ cult $\times$ Tricho & 1 & 0.41 & 0.55 & 0.65 & 0.56 & 0.88 & 0.77 & 0.43 \\
\hline Bed $\times$ cult $\times$ mtlxl & 1 & 0.92 & 0.20 & 0.39 & 0.06 & 0.18 & 0.73 & 0.76 \\
\hline Cult $\times$ mtlxl $\times$ Tricho & 1 & 0.75 & 0.40 & 0.15 & 0.80 & 0.66 & 0.90 & 0.52 \\
\hline Error & 98 & & & & & & & \\
\hline
\end{tabular}

a Mean square value and degrees of freedom for the bed height $\times$ replicate interaction were used for the error term to calculate the $F$ statistics and determine the associated significance values pertaining to the main effect of bed height.

Table 4. Interactions between raspberry cultivar and cultural or chemical control factors with respect to disease incidence, growth, and yield in a planting naturally infested with Phytophthora fragariae var. rubi

\begin{tabular}{|c|c|c|c|c|c|c|c|}
\hline \multirow[b]{3}{*}{ Cultivar } & \multirow[b]{3}{*}{ Factor } & \multirow[b]{3}{*}{ Level } & \multicolumn{3}{|c|}{1992 season } & & \\
\hline & & & \multirow[b]{2}{*}{ Cane no. } & \multicolumn{2}{|c|}{ \% diseased canes } & \multicolumn{2}{|c|}{1993 season } \\
\hline & & & & 2 July & 25 August & Cane no. & Yield (kg) \\
\hline \multirow[t]{2}{*}{ Newburgh } & Bed & Raised & $\mathrm{NS}^{\mathrm{a}}$ & $1.1 * * *$ & NS & $149.3 *$ & $5.57 * *$ \\
\hline & & Flat & $\ldots^{\mathrm{b}}$ & 1.2 & $\ldots$ & 93.2 & 2.00 \\
\hline \multirow{2}{*}{ Titan } & Bed & Raised & $\ldots$ & 8.3 & $\ldots$ & 20.2 & 0.48 \\
\hline & & Flat & & 48.9 & & 4.5 & 0.07 \\
\hline \multirow{2}{*}{ Newburgh } & Mulch & Yes & $113.6^{*}$ & $4.4^{*}$ & $13.1 * *$ & NS & NS \\
\hline & & No & 84.3 & 0.5 & 2.8 & $\ldots$ & $\ldots$ \\
\hline \multirow[t]{2}{*}{ Titan } & Mulch & Yes & 9.7 & 56.9 & 88.9 & $\ldots$ & $\ldots$ \\
\hline & & No & 20.4 & 21.5 & 35.4 & $\ldots$ & $\ldots$ \\
\hline \multirow[t]{2}{*}{ Newburgh } & Metalaxyl & Yes & NS & $0.0 * *$ & $2.1^{*}$ & NS & NS \\
\hline & & No & $\ldots$ & 1.9 & 6.7 & $\ldots$ & $\ldots$ \\
\hline \multirow[t]{2}{*}{ Titan } & Metalaxyl & Yes & $\ldots$ & 12.5 & 26.4 & $\ldots$ & $\ldots$ \\
\hline & & No & $\ldots$ & 39.4 & 59.3 & $\ldots$ & $\ldots$ \\
\hline
\end{tabular}


dence generally remained low for Newburgh regardless of treatment (Table 4). Thus, it appears that the significant main effect on disease incidence for both of these factors (Table 3) was due more to their pronounced influence on Titan than to their modest influence on Newburgh. Similarly, near the start of the epidemic (July 1992), raised beds reduced disease incidence on Titan to $<10 \%$ versus nearly $50 \%$ on flat beds, whereas practically no disease was evident on Newburgh at this time regardless of bed height (Table 4$)$. Raised beds also interacted $(P<0.03)$ with straw mulch with respect to mean cane diameter at the end of the 1992 season. For raised beds, this value decreased from 9.1 $\mathrm{mm}$ on bare ground to $7.5 \mathrm{~mm}$ when mulch was applied. In contrast, canes were generally less robust on flat beds; hence the decrease from 6.9 to $6.2 \mathrm{~mm}$ in the bare versus mulched plots, respectively, was less pronounced. Bed height was a factor in three of the five two-way interactions with $P<0.05$, and in five of the 11 with $P$ $<0.10$ (Table 3).

Correlation analysis showed a strong association $(r=0.73$ to $0.83, P<0.01$ ) among measurements of cane density, length, and diameter (Table 5). Cane diameter in the autumn of 1992 was a better predictor of the following year's yield than was cane length $(r=0.73$ versus 0.63 , respectively), and both were better predictors than was cane density (Table 5). The strongest association between dependent variables $(r=-0.80, P<0.01)$ was that for yield in 1993 versus disease incidence on the August 1992 assessment date. Disease incidence levels in 1992 also were strongly correlated (negatively) with mean soil water tension measurements during the same season and, to a lesser extent, with this variable in 1991 (Table 5). Tensiometer readings were significantly $(P<0.05)$ lower (i.e., soil was significantly wetter) in mulched versus unmulched plots on 13 dates in 1991 and on 8 dates in 1992 (Fig. 1), but differences were seldom significant between raised and flat beds at the $25-\mathrm{cm}$ soil depth where these measurements were made (data not shown).

\section{DISCUSSION}

Our results demonstrate the influence of various cultural, chemical, and biological factors on the occurrence and control of PRR, but it is clear that strong differences in cultivar susceptibility overwhelmed the effects of all other factors under these specific test conditions. Maloney et al. (9) found that a planting system with slightly higher raised beds than those used in our study $(36$ and $32 \mathrm{~cm}$ at the start and finish of their experiment versus 30 and $20 \mathrm{~cm}$ in ours, respectively) provided substantial control of PRR on Titan plants grown in an infested silt loam near Geneva, New York; however, Titan was severely diseased in our trial regardless of treatment. In contrast, Newburgh plants responded positively to the raised bed treatment, and this was the only factor other than cultivar to have a significant effect on yield. The generally poor performance of Titan and the limited degrees of freedom for the error term associated with bed height as a main factor depressed its statistical significance with respect to measures of disease incidence and severity, although its positive effect was apparent in interactions with other factors.

It has been assumed $(5,9)$ that raised beds reduce disease severity by providing a rooting zone in which soil water tensions generally exceed those supportive of significant zoospore release and motility. However, it is likely that levels of zoospore activity qualifying as significant will vary according to cultivar susceptibility. In greenhouse tests, for example, $P$. fragariae var. rubi caused high levels of disease on Titan plants when infested soil was irrigated daily without periods of waterlogging, whereas all unrelated cultivars showed little disease unless waterlogging was imposed (25). Presumably, these results reflect differential cultivar responses to the lower zoospore densities in unsaturated versus saturated media, respectively; for instance, Duncan and Kennedy (3) showed that waterlogging had little effect on the response of susceptible versus moderately resistant cultivars if imposed subsequent to inoculation with $P$. fragariae var. rubi zoospores. The effect of soil water tension on zoospore activity has not been reported for this Phytophthora sp. However, MacDonald and Duniway (8) showed that, whereas both $P$. megasperma and $P$. cryptogea released optimal numbers of zoospores under saturated soil conditions, they also released approximately 35 and $10 \%$ as many at tensions of 0.5 and 1.0 $\mathrm{kPa}$, respectively. These values correspond to the respective equilibrium tensions in soil 5 and $10 \mathrm{~cm}$ above puddled water surrounding a raised planting bed. Furthermore, sporangia of several Phytophthora spp. begin discharging zoospores within 1 to $2 \mathrm{~h}$ after the onset of saturated soil conditions (24). Thus, we believe that unusually frequent and prolonged rainfall during the 1992 summer provided periods at or near saturation in the raised beds, which allowed zoospore activity sufficient to cause severe disease on the highly susceptible Titan cultivar in our study. Apparently, such was not the case in previous studies $(5,9)$, where highly susceptible cultivars were much less diseased on raised beds.

Straw mulch was included as a treatment because a previous study (17), in the presumed absence of $P$. fragariae var. rubi, showed it to be useful in helping to establish new plantings by (i) controlling weeds while avoiding the phytotoxicity that often affects young tissue-cultured raspberry plants treated with standard preemergence herbicides (12), and (ii) maintaining ample supplies of soil moisture to promote optimal plant growth. Indeed, Newburgh primocane numbers were increased in the mulched versus unmulched plots in 1992 when the incidence of symptomatic plants was modest (Table 4). However, the higher soil moisture levels provided by the mulch generally appear to have favored the development of PRR to the net detriment of

Table 5. Correlations ${ }^{\mathrm{a}}$ among and between soil water tension (SWT) measurements and those used to assess plant responses to imposed cultural, chemical, and biological treatments

\begin{tabular}{|c|c|c|c|c|c|c|c|c|c|c|}
\hline & $\begin{array}{l}\text { SWT } \\
1991\end{array}$ & $\begin{array}{l}\text { SWT } \\
1992\end{array}$ & $\begin{array}{l}\text { SWT } \\
1993\end{array}$ & $\begin{array}{l}\text { Dis. inc } \\
\text { Jul. } 92\end{array}$ & $\begin{array}{l}\text { Dis. inc. } \\
\text { Aug. } 92\end{array}$ & $\begin{array}{c}\text { Cane no. } \\
\text { Oct. } 92\end{array}$ & $\begin{array}{c}\text { Cn. lgth. } \\
\text { Oct. } 92\end{array}$ & $\begin{array}{c}\text { Cn. diam. } \\
\text { Oct. } 92\end{array}$ & $\begin{array}{c}\text { Cane no. } \\
\text { Sep. } 93\end{array}$ & $\begin{array}{l}\text { Yield } \\
1993\end{array}$ \\
\hline Soil water tension/1991 b & 1.000 & 0.758 & 0.734 & -0.356 & -0.325 & 0.232 & 0.421 & 0.437 & 0.151 & 0.303 \\
\hline Soil water tension $/ 1992^{c}$ & & 1.000 & 0.518 & -0.599 & -0.619 & 0.490 & 0.649 & 0.680 & 0.556 & 0.303 \\
\hline Soil water tension/1993 & & & 1.000 & -0.347 & -0.032 & 0.351 & 0.480 & 0.393 & 0.125 & 0.052 \\
\hline Disease incidence/Jul. 92 & & & & 1.000 & 0.733 & -0.668 & -0.764 & -0.730 & -0.611 & -0.713 \\
\hline Diseases incidence/Aug. 92 & & & & & 1.000 & -0.509 & -0.532 & -0.681 & -0.490 & -0.802 \\
\hline Cane number/Oct. 92 & & & & & & 1.000 & 0.827 & 0.729 & 0.593 & 0.465 \\
\hline Cane length/Oct. 92 & & & & & & & 1.000 & 0.828 & 0.665 & 0.631 \\
\hline Cane diameter/Oct. 92 & & & & & & & & 1.000 & 0.601 & 0.730 \\
\hline Cane number/Sep. 93 & & & & & & & & & 1.000 & 0.650 \\
\hline Yield/1993 & & & & & & & & & & 1.000 \\
\hline
\end{tabular}


the plants, similar to the experiences of Merwin et al. (10) in an apple planting adjacent to this site and of Heiberg (5) in a raspberry planting in Norway. Thus, in an effort to balance the risks versus benefits of a mulch application, we currently recommend that it be used only in the establishment year of new raspberry plantings when the danger of herbicide injury is greatest, and that the mulch be removed quickly if symptoms of PRR become apparent.

Although metalaxyl initially provided a substantial decrease in disease incidence on Titan during the summer of 1992, most plants of this cultivar eventually succumbed, providing little yield or new primocane growth the following year. In con- trast, metalaxyl provided modest yield benefits for Newburgh, i.e., means of 2.2 versus $1.8 \mathrm{~kg}$ for the treated versus untreated plots on flat beds and 6.3 versus 5.1 $\mathrm{kg}$, respectively, on raised beds. Our results are consistent with those of Maloney et al. (9), who found no benefit from metalaxyl under their highest disease pressure conditions (Titan on flat beds) but obtained modest additional gains when the fungicide was applied in conjunction with a more effective treatment (raised beds). In contrast, Heiberg (5) found that metalaxyl and raised beds were equally effective in controlling the disease, although the combination of the two was superior to either alone.

Incorporating the biocontrol fungus $T$. virens into the planting hole produced only
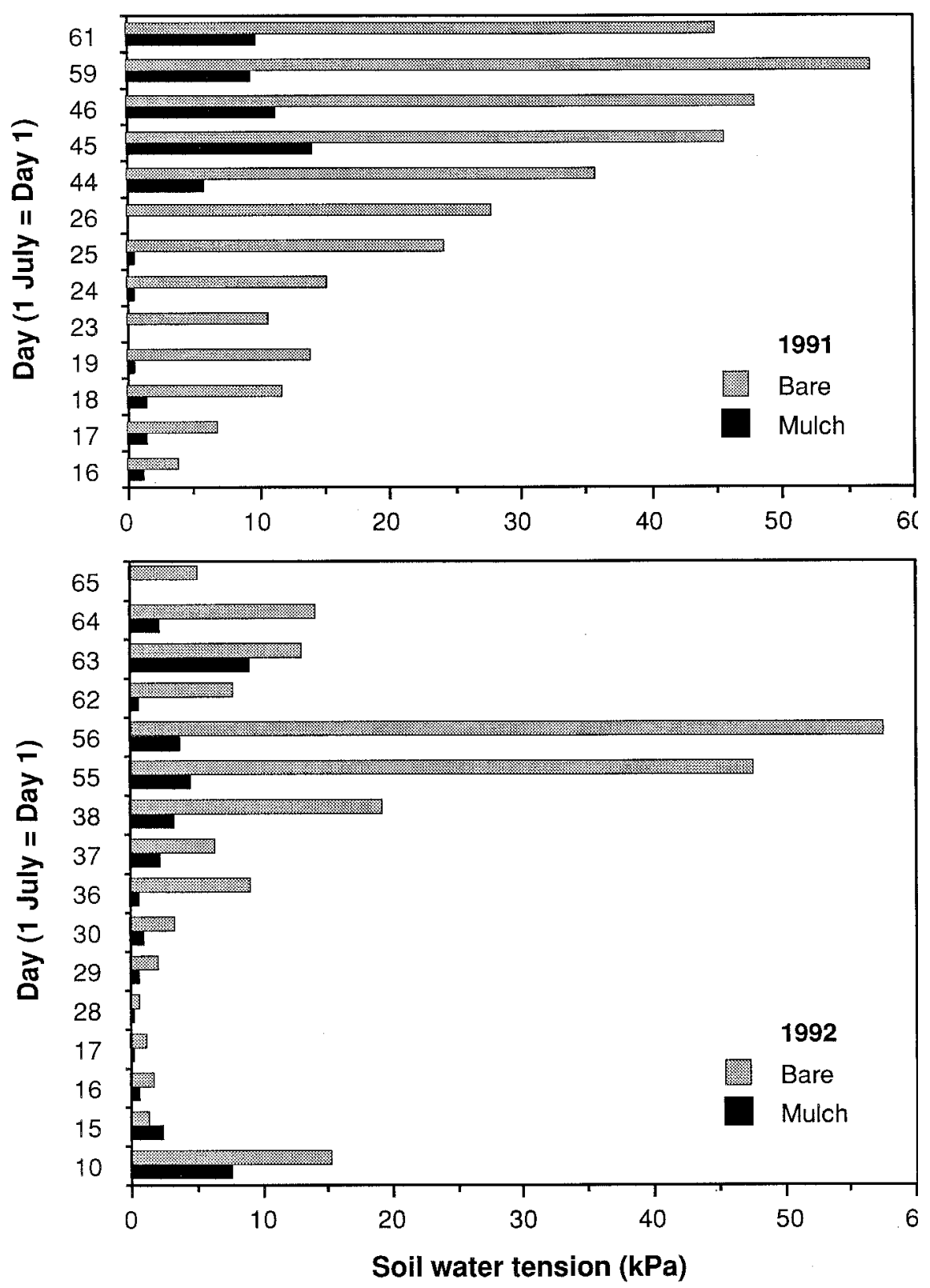

Fig. 1. Comparative soil water tensions in mulched versus unmulched (bare) plots. Values for each date represent the mean tensiometer readings from nine mulched and nine bare plots. Differences between the two were significant $(P<0.05)$ on all dates in 1991 and on days $29,30,36,38,55,56$, 64, and 65 in 1992.

marginal effects on the various measures of disease incidence and severity other than 1993 primocane densities; unfortunately, termination of the experiment before such canes fruited the following year precludes an assessment of this response's impact. Similarly, it is unclear whether the contrast between this significant response in 1993 versus the insignificant effects on disease incidence and severity the previous year reflects a limited biocontrol potential for $T$. virens, which was realized more effectively under the dry conditions of 1993 than the wet conditions of 1992. Preliminary analysis of data from a related, subsequent trial (26) is consistent with this hypothesis.

Our results suggest several practical recommendations with respect to integrated programs for control of PRR, assuming that inoculum of $P$. fragariae var. rubi is present: (i) highly susceptible cultivars such as Titan should be avoided on soils where drainage is problematic, even if they are tiled; (ii) raised bed cultivation is the most effective control component other than varietal selection, but it will not necessarily permit successful growth of a highly susceptible cultivar under high rainfall conditions; (iii) metalaxyl (and presumably its active enantiomer, mefanoxam) has limited potential under high disease pressure conditions but may provide additional benefit when combined with more effective control components, e.g., moderately resistant varieties and raised bed cultivation; and (iv) horticultural practices that increase soil moisture (e.g., mulching) should be monitored closely for potentially negative effects on PRR, which might negate their otherwise positive effects on plant growth.

\section{LITERATURE CITED}

1. Converse, R. H. 1966. Diseases of Raspberries and Erect and Trailing Blackberries. Pages 41-42 in: U.S. Dep. Agric. Handb. 310.

2. Converse, R. H., and Schwartze, C. D. 1968. A root rot of red raspberry caused by Phytophthora erythroseptica. Phytopathology 58:56-59.

3. Duncan, J. M., and Kennedy, D. M. 1989. The effect of waterlogging on Phytophthora root rot of red raspberry. Plant Pathol. 38:161-168.

4. Duncan, J. M., Kennedy, D. M., and Seemüller, E. 1987. Identities and pathogenicities of Phytophthora spp. causing root rot of red raspberry. Plant Pathol. 36:276-289.

5. Heiberg, N. 1995. Control of root rot of red raspberries caused by Phytophthora fragariae var. rubi. Plant Pathol. 44:153-159.

6. Heiberg, N., Duncan, J. M., Kennedy, D. M., and Semb, L. 1989. Raspberry root rot in Norway. Acta Hortic. 262:189-191.

7. Latorre, B. A., and Muñoz, R. 1993. Root rot of red raspberry caused by Phytophthora citricola and $P$. citrophthora in Chile. Plant Dis. 77:715-718.

8. MacDonald, J. D., and Duniway, J. M. 1978. Influence of the matric and osmotic components of water potential on zoospore discharge in Phytophthora. Phytopathology 68:751-757.

9. Maloney, K., Wilcox, W. F., and Sanford, J. C. 1993. Effects of raised beds and metalaxyl for 
control of Phytophthora root rot of raspberry. HortScience 28:1106-1108.

10. Merwin, I. A., Wilcox, W. F., and Stiles, W. C. 1992. Influence of orchard ground cover management on the development of Phytophthora crown and root rots of apple. Plant Dis. 76:199-205.

11. Montgomerie, I. G., and Kennedy, D. M. 1980. The pathogenicity of Phytophthora species to red raspberry. Acta Hortic. 112:167-176.

12. Neal, J. C., Pritts, M. P., and Senesac, A. F. 1990. Evaluation of pre-emergence herbicide phytotoxicity to tissue culture-propagated Heritage red raspberry. J. Am. Soc. Hortic. Sci. 115:416-422.

13. Nourisseau, J.-G., and Baudry, A. 1987. Un Phytophthora cause de deperissement du framboisier en France. Phytoma 384:39-41.

14. Pritts, M., and Handley, D., eds. 1989. Bramble Production Guide. Northeast Regional Agric. Eng. Serv., Ithaca, NY.

15. Seemüller, E., Duncan, J. M., Kennedy, D. M., and Riedel, M. 1986. Phytophthora sp. als Ursache einer Wurzelfäule an Himbeere. Nachrichtenbl. Dtsch. Pflanzenschutz. 38:1721

16. Smith, V. L., Wilcox, W. F., and Harman, G.
E. 1990. Potential for biological control of Phytophthora root and crown rots of apple by Trichoderma and Gliocladium spp. Phytopathology 80:880-885.

17. Trinka, D. L., and Pritts, M. P. 1992. Micropropagated raspberry plant establishment responds to weed control practice, row cover use, and fertilizer placement. J. Am. Soc. Hortic. Sci. 117:874-880

18. Washington, W. S. 1988. Phytophthora cryptogea as a cause of root rot of raspberry cultivars and control with fungicides. Plant Pathol. 37:225-230.

19. Waterson, J. M. 1937. A note on the association of a species of Phytophthora with a 'dieback' disease of the raspberry. Trans. R. Soc. Edinburgh 32:251-259.

20. Wilcox, W. F. 1989. Identity, virulence, and isolation frequency of seven Phytophthora spp. causing root rot of red raspberry in New York. Phytopathology 79:93-101.

21. Wilcox, W. F. 1991. Phytophthora root rot. Pages 34-36 in: Compendium of Raspberry and Blackberry Diseases and Insects. M. A. Ellis, R. H. Converse, R. N. Williams, and B. Williamson, eds. American Phytopathological Society, St. Paul, MN.

22. Wilcox, W. F., Harman, G. E., and Di Pietro,
A. 1992. Effect of gliotoxin on growth, sporulation, and zoospore motility of seven Phytophthora spp. in vitro. (Abstr.) Phytopathology 82:1121.

23. Wilcox, W. F., and Latorre, B. A. 1995. Identity and distribution of Phytophthora spp. causing root rot of raspberry in Chile. (Abstr.) Phytopathology 85:1150.

24. Wilcox, W. F., and Mircetich, S. M. 1985. Influence of soil water matric potential on the development of Phytophthora root and crown rots of Mahaleb cherry. Phytopathology 75:648-653.

25. Wilcox, W. F., Nevill, J. R., and Burr, J. A Susceptibility of red, black, and purple raspberry cultivars to three Phytophthora species under greenhouse and field conditions. Acta Hortic. In press.

26. Wilcox, W. F., Ondik, K. L., and Harman, G. E. 1997. Integrated control of Phytophthora root rot of raspberry. (Abstr.) Phytopathology 87:S102.

27. Wilcox, W. F., Scott, P. H., Hamm, P. B Kennedy, D. M., Duncan, J. M., Brasier, C. M., and Hansen, E. M. 1993. Identity of a Phytophthora species attacking raspberry in Europe and North America. Mycol. Res. 97:817-831. 